Original article

\title{
Effect of the type of concentrate, cereals vs. sugar beet pulp, on rumen fermentation, plasma concentration of methylmalonate and quality of subcutaneous adipose tissue of intensively reared lambs
}

\author{
Jérôme NORMAND ${ }^{\mathrm{a} *}$, Michel THÉRIEZ ${ }^{\mathrm{b}}$, Pierre BAS ${ }^{\mathrm{c}}$, \\ Valérie Berthelot $^{\mathrm{c}, \mathrm{d}}$, Bernard Aurousseau ${ }^{\mathrm{e}}$, Daniel SAUVANT ${ }^{\mathrm{c}}$ \\ a Institut de l'Élevage, Service Viande, Ester, 87069 Limoges Cedex, France \\ b INRA, Laboratoire Adaptation des Herbivores aux Milieux, Theix, \\ 63122 Saint-Genès-Champanelle, France \\ c UMR Physiologie de la Nutrition et Alimentation INRA-INAPG, 16 rue Claude-Bernard, \\ 75231 Paris Cedex 05, France \\ d Danish Institute of Agricultural Sciences, Department of Animal Nutrition and Physiology, \\ PO Box 50, 8830 Tjele, Denmark \\ e INRA, Unité de Recherches sur les Herbivores, Équipe Nutriments et Métabolismes, Theix, \\ 63122 Saint-Genès-Champanelle, France
}

(Received 30 August 1999; accepted 21 June 2001)

\begin{abstract}
The aim of this study was to investigate the effect of substituting wheat and barley by sugar beet pulp on the quality of subcutaneous adipose tissue of intensively reared lambs. Rumen fermentation and methylmalonate plasma concentration, both considered as indicators of lamb metabolism, were also studied. Forty-nine male lambs of the Lacaune dairy breed were fed from $23.6( \pm 4.1) \mathrm{kg}$ to $41.0( \pm 1.9) \mathrm{kg}$ live weight with hay and a pelleted concentrate containing either wheat and barley (80\%, group C) or sugar beet pulp (70\%, group P). Rumen fluid samples were collected at $0,1,2$, 4 or 6 hours after the last meal before slaughter from 5 lambs per diet at each time. The plasma concentration of methylmalonate was measured in two samples per lamb collected 12 and $36 \mathrm{~d}$ before slaughter. The calculated metabolisable energy intake and average daily gain were not significantly different between group C and P $\left(3.27 \mathrm{Mcal} \cdot \mathrm{d}^{-1}\right.$ and $\left.309 \mathrm{~g} \cdot \mathrm{d}^{-1}\right)$. Six hours after the last meal, the rumen concentration of total volatile fatty acids was higher in group $\mathrm{C}$ than in group $\mathrm{P}\left(186 \mathrm{vs} .137 \mathrm{mmol} \cdot \mathrm{L}^{-1}\right.$, $P<0.01)$ and the acetate/propionate ratio was lower $(0.91$ vs. $2.07, P<0.01)$. The average concentration of methylmalonate in plasma was higher in group $\mathrm{C}$ than in group $\mathrm{P}\left(2.76 \mathrm{vs} .1 .92 \mu \mathrm{mol} \cdot \mathrm{L}^{-1}\right.$, $P=0.09)$. However, the diet had no significant effects on the firmness and colour of subcutaneous adipose tissue; globally, the quality was poor. No relationship between plasma concentration of methylmalonate and fat firmness scores was observed.
\end{abstract}

lamb / sugar beet pulp / volatile fatty acid / methylmalonate / quality

* Correspondence and reprints

Tel.: 33 (0)5 554260 90; fax: 33 (0)5 554260 95; e-mail: jerome.normand @ inst-elevage.asso.fr 
Résumé - Effet de la nature de l'aliment concentré, céréales vs. pulpes de betteraves, sur les fermentations ruminales, la concentration plasmatique en méthylmalonate et la qualité des gras de couverture d'agneaux de bergerie. Le but de ce travail était de vérifier l'effet de l'introduction de pulpes de betteraves dans le régime sur la qualité du gras de couverture des agneaux de bergerie, en s'intéressant plus particulièrement aux fermentations ruminales et aux concentrations plasmatiques en méthylmalonate, pris comme critères d'estimation du métabolisme des agneaux. Ainsi, 49 agneaux mâles, de race Lacaune « lait », ont été engraissés de $23,6( \pm 4,1)$ à $41,0( \pm 1,9) \mathrm{kg}$. Ils disposaient en libre accès de foin et d'un aliment concentré aggloméré composé de $80 \%$ de céréales (lot C) ou de $70 \%$ de pulpes de betteraves (lot P). Des échantillons de jus de rumen ont été prélevés lors de l'abattage, $0,1,2,4$ ou 6 heures après la distribution du dernier repas, sur en moyenne 5 agneaux par temps et par régime. La concentration plasmatique en méthylmalonate a été mesurée sur 2 prélèvements effectués 12 et 36 jours avant abattage. L'ingestion d'énergie métabolisable calculée et la vitesse de croissance n'ont pas été significativement différentes sur la période de finition $\left(3,27 \mathrm{Mcal} \cdot \mathrm{j}^{-1}\right.$ et $\left.309 \mathrm{~g} \cdot \mathrm{j}^{-1}\right)$. Six heures après le début du repas, les concentrations ruminales en acides gras volatils totaux ont été plus élevées dans le lot $\mathrm{C}$ que dans le lot $\mathrm{P}\left(186 \mathrm{vs} .137 \mathrm{mmol} \cdot \mathrm{L}^{-1}\right.$, $p<0,01)$ et le rapport acétate/propionate plus faible $(0,91$ vs. $2,07, p<0,01)$. Les concentrations plasmatiques moyennes en méthylmalonate du lot $\mathrm{C}$ ont été supérieures à celles du lot $\mathrm{P}$ (2,76 vs. $\left.1,92 \mu \mathrm{mol} \cdot \mathrm{L}^{-1}, p=0,09\right)$. Cependant, aucune influence significative du régime n'a été observée sur la fermeté et la couleur du gras sous-cutané ; la qualité des gras n'a été satisfaisante dans aucun des deux lots. Par ailleurs, aucune liaison n'a été mise en évidence entre les notes de fermeté du gras et les concentrations plasmatiques en méthylmalonate.

agneau / pulpes de betteraves / acides gras volatils / méthylmalonate / qualité

\section{INTRODUCTION}

The quality of subcutaneous fat is a current concern in French intensively-reared lamb production. Problems of firmness and colour of fat can appear in up to two-thirds of lamb production in some French areas and in some specific breeds [21]: the subcutaneous adipose tissues, usually firm and white, present a soft/oily texture and/or coloured fat (from light cream to brownred). These problems lead to exclusion of carcasses from quality trade markets and result therefore in financial losses of 5 to $15 \%$ of the initial market price for farmers.

Many trials have shown the effects of feeding during the fattening period of growing lambs on fat quality $[9,10,33]$. Diets rich in wheat or in barley seem to decrease the firmness of subcutaneous adipose tissue $[1,13,26]$. These diets lead to high ruminal production of propionate which, after its absorption, could exceed the capacity of the liver to metabolise it into glucose.
Thus the excess of propionate might be either used as a precursor for the synthesis of odd-numbered fatty acids or metabolised into methylmalonate which is a precursor of methyl branched-chain fatty acids [14, 30]. The melting point of these fatty acids is low and therefore they contribute to the soft adipose tissue problem [3, 7, 12].

The substitution of cereals by other feedstuffs producing more acetate and less propionate during ruminal fermentation is often recommended to limit the occurrence of the problems of carcass quality. Partial or total substitution of cereals by sugar beet pulp was tested in several experiments. The results on fat quality are variable. Matray et al. [22] reported an improvement in firmness and colour of adipose tissues, Thériez and Brun [31] and Sagot (personal communication) reported no modification, and Normand et al. [24] showed a trend of degradation of fat quality. Several hypotheses have been proposed to explain the variability of responses. According to these trials, 
the incorporation of sugar beet pulp in the diets does not have similar effects on the average daily gain (ADG). It is therefore possible that the effect due to growing rates may have hidden the effects due to the type of feed eaten. Moreover, ruminal production of propionate from beet pulp fermentation may be quite similar to its production arising from cereal-based diet fermentation. This could counterbalance the supposed favourable effect of a sugar beet pulp diet. A complementary study is necessary to confirm the effect of the type of feed, cereals vs. beet pulp, on subcutaneous fat quality of intensively reared lambs. Particular attention was paid to ruminal fermentation and to plasma concentration of methylmalonate in order to estimate lamb metabolism.

\section{MATERIALS AND METHODS}

\subsection{Animals and treatments}

Forty-nine male lambs of the Lacaune Dairy breed, sired from 8 rams, were suckled until 4 weeks of age and then were abruptly weaned. At $53( \pm 5)$ days, they were individually penned on a slatted floor and split into two groups according to the criteria of paternal origin, age and weight at the beginning of the experiment. After 10 days of adaptation, the lambs were given free access to second cut meadow hay (metabolisable energy (ME): $2.39 \mathrm{Mcal} \cdot \mathrm{kg}^{-1}$ dry matter (DM), crude protein: $195 \mathrm{~g} \cdot \mathrm{kg}^{-1}$ DM, INRA tables [17]) and to a pelleted concentrate feed, rich in cereals (group C) or in beet pulp (group P). Their composition and nutritional values are presented in Table I. The lambs were slaughtered as soon as their live weight reached $39 \mathrm{~kg}$ at the weekly weighing.

\subsection{Samplings and measurements}

The measurements of average daily gain (6 to 13 weighings per lamb), feed intake,
Table I. Composition and nutritional values of the experimental concentrates.

\begin{tabular}{|c|c|c|}
\hline & Cereal & Beet pulp \\
\hline \multicolumn{3}{|l|}{ Composition $(\% \mathrm{DM})^{\mathrm{a}}$} \\
\hline Barley & 45.9 & - \\
\hline Wheat & 34.7 & - \\
\hline Oat & - & 9.9 \\
\hline Sugar beet pulp & - & 70.8 \\
\hline Soybean meal & 5.0 & 4.9 \\
\hline Rapeseed meal & 4.1 & 5.0 \\
\hline Fish meal & 4.2 & 4.1 \\
\hline Molasses & 2.6 & 2.6 \\
\hline Urea & - & 0.4 \\
\hline Ammonia chloride & 1.1 & 1.1 \\
\hline Calcium carbonate & 2.3 & - \\
\hline $\begin{array}{l}\text { Sodium dihydrogen } \\
\text { phosphate }\end{array}$ & - & 1.1 \\
\hline \multicolumn{3}{|c|}{ Chemical composition (\% DM) } \\
\hline Ash & 6.0 & 8.9 \\
\hline Crude protein & 22.7 & 20.5 \\
\hline Crude fibre & 4.8 & 17.7 \\
\hline Ether extract & 2.5 & 2.1 \\
\hline NDF & 17.3 & 42.6 \\
\hline $\mathrm{ADF}$ & 6.5 & 19.9 \\
\hline ADL & 1.6 & 2.0 \\
\hline Starch & 56.0 & 11.3 \\
\hline Metabolisable energy & & \\
\hline $\begin{array}{l}\left(\text { Mcal } \cdot \mathrm{kg}^{-1} \mathrm{DM}\right)^{\mathrm{b}} \\
\text { PDIN }\left(\mathrm{g} \cdot \mathrm{kg}^{-1} \mathrm{DM}\right)^{\mathrm{c}}\end{array}$ & $\begin{array}{c}2.96 \\
131\end{array}$ & $\begin{array}{l}2.68 \\
125\end{array}$ \\
\hline PDIE $\left(g \cdot k^{-1} D M\right)^{c}$ & 129 & 129 \\
\hline
\end{tabular}

a The mineral premix $(\mathrm{Cu}, \mathrm{Zn}, \mathrm{Co}, \mathrm{I}, \mathrm{Se})$ was brought into solution.

${ }^{\mathrm{b}}$ Calculated from chemical analyses [15].

${ }^{c}$ Calculated from tables of feed values [17].

plasma concentrations of glucose, insulin, non-esterified fatty acids (NEFA), $\beta$-hydroxybutyrate (BHB) and lactate (3 to 6 blood samplings per lamb) as well as the measurements of the fattening status are presented by Normand et al. [24]. The firmness and colour of subcutaneous fat were judged on cooled carcasses according to the scale of the Institut de l'Élevage (1: very firm and very white fat to 5: very soft/oily and coloured fat [21]). 
In order to estimate the changes in ruminal concentration of short-chain fatty acids (SCFA) during the early hours of digestion, rumen fluid was sampled after $0,1,2,4$ or 6 hours after the last diet offered before slaughter, on respectively $4,6,3,5$, and 5 lambs of group $\mathrm{C}$ and on 4, 5, 5, 5, and 5 lambs of group P. For the 12 hours previous to the distribution of the last meal, the lambs had no access to the diet. A preservative $\left(0.1 \mathrm{~mL} \mathrm{H}_{3} \mathrm{PO}_{4} \cdot \mathrm{mL}^{-1}\right.$ of rumen fluid $)$ was added to the samples before freezing and storage at $-30{ }^{\circ} \mathrm{C}$. The concentrations of SCFA were determined by gas-liquid chromatography according to the method described by Jouany [19].

The plasma concentration of methylmalonate was determined by gas-liquid chromatography according to the method described by Berthelot et al. [5] on blood sampled $36 \pm 15\left(\mathrm{t}_{-36}\right)$ and $12 \pm 3\left(\mathrm{t}_{-12}\right)$ days before slaughter.

\subsection{Statistical analyses}

Data were analysed by variance-covariance analysis according to the Mixed procedure for unbalanced designs of SAS [27, 28]. In the model, the type of concentrate was used as a fixed factor. The paternal origin and the interaction, paternal origin $x$ type of concentrate, were used as random factors, with the weight at the beginning of the experiment as a covariable. The linear relationships between each variable were studied. The plasma concentrations of each metabolite measured during the experiment were averaged.

The ruminal concentrations of SCFA were studied by analysis of variance using the type of concentrate, duration of intake before rumen sampling and interaction type of concentrate $\times$ duration of intake in the model. For each sampling time, the leastsquares means of the groups $\mathrm{C}$ and $\mathrm{P}$ were compared with a $t$-test.

\section{RESULTS}

Despite the small number of lambs per ram, the paternal origin was maintained in the statistical model as a way of grouping the lambs at the beginning of the experiment. The paternal origin had an influence on the ADG $(P=0.15)$ but had no significant effect on the diet intake, nutritional status and carcass quality. Therefore, it will not be mentioned any longer in the present text.

\subsection{Feeding, growth and fattening duration}

Lamb performances are presented in Table II. At the beginning of the experiment, i.e. after 10 days of adaptation, the lambs in group $\mathrm{P}$ were heavier than the ones in group C (24.1 vs. $22.3 \mathrm{~kg}, P=0.10)$. During the fattening period, feed intake of group $\mathrm{P}$ was greater compared to group $\mathrm{C}$ (+ $\left.0.14 \mathrm{~kg} \mathrm{DM} \cdot \mathrm{d}^{-1}, P<0.01\right)$. However, the percentage of hay intake was lower in group P (17.0 vs. $18.5 \%$ hay in DM intake, $P=0.12$ ). The ME intake was not significantly different between the 2 groups $\left(3.27 \mathrm{Mcal} \cdot \mathrm{d}^{-1}\right)$. The growth rates between the $\mathrm{P}$ and $\mathrm{C}$ groups were similar $\left(309 \mathrm{~g} \cdot \mathrm{d}^{-1}\right)$. Therefore, the feed conversion index ( $\mathrm{kg}$ DM intake $\cdot \mathrm{kg}^{-1}$ weight gain) of the lambs was significantly greater for the $\mathrm{P}$ group compared to the $\mathrm{C}$ group $\left(+0.38 \mathrm{~kg} \mathrm{DM} \cdot \mathrm{kg}^{-1}\right.$ weight gain, $P<0.05)$. But the energy conversion index (Mcal ME intake $\cdot \mathrm{kg}^{-1}$ weight gain) was not different between the 2 diets. Nitrogen conversion was better for the $\mathrm{C}$ diet compared to the $\mathrm{P}$ diet according to the PDI French protein value system [17] (respectively, 483 vs. $512 \mathrm{~g} \mathrm{PDIN} \cdot \mathrm{kg}^{-1}$ gain $(P=0.09)$ and 462 vs. $510 \mathrm{~g} P D I E \cdot \mathrm{kg}^{-1}$ gain $(P<0.05))$.

Live weight before slaughter $(40.9 \mathrm{~kg})$ and cold carcass weight $(18.6 \mathrm{~kg})$ were not significantly different between the 2 diets. Since the ADG was similar for the 2 diets, the fattening period was also similar for the 
Table II. Effect of the type of concentrate on growth performances.

\begin{tabular}{|c|c|c|c|c|}
\hline & $\begin{array}{c}\text { Cereal } \\
(n=25)\end{array}$ & $\begin{array}{c}\text { Beet pulp } \\
(n=24)\end{array}$ & $\mathrm{RSD}^{\mathrm{a}}$ & Probability \\
\hline DM intake $\left(\mathrm{kg} \cdot \mathrm{d}^{-1}\right)$ & 1.12 & 1.26 & 0.10 & $P<0.01$ \\
\hline Hay (\% DM intake) & 18.5 & 17.0 & 2.6 & $P=0.12$ \\
\hline 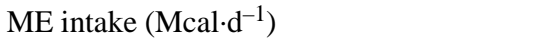 & 3.20 & 3.32 & 0.29 & NS \\
\hline ME intake $\cdot \mathrm{kg}^{-1} \mathrm{LW}^{0.75}\left(\mathrm{Mcal} \cdot \mathrm{d}^{-1} \cdot \mathrm{kg}^{-1}\right)$ & 0.24 & 0.26 & 0.02 & $P=0.14$ \\
\hline Initial live weight (kg) & 22.3 & 24.1 & 3.2 & $P=0.10$ \\
\hline Live weight at slaughter $(\mathrm{kg})$ & 40.9 & 40.9 & 1.4 & NS \\
\hline Adjusted $\mathrm{ADG}^{\mathrm{b}}\left(\mathrm{g} \cdot \mathrm{d}^{-1}\right)$ & 305 & 312 & 40 & NS \\
\hline Feed conversion index (kg DM. $\mathrm{kg}^{-1}$ gain) & 3.72 & 4.10 & 0.38 & $P<0.05$ \\
\hline Energy conversion index (Mcal $\cdot \mathrm{kg}^{-1}$ gain $)$ & 10.63 & 10.77 & 1.02 & NS \\
\hline Index PDIN (g PDIN·kg ${ }^{-1}$ gain) & 483 & 512 & 48 & $P=0.09$ \\
\hline Index PDIE (g PDIE $\cdot \mathrm{kg}^{-1}$ gain) & 462 & 510 & 47 & $P<0.05$ \\
\hline Age at slaughter (d) & 123 & 123 & 7 & NS \\
\hline Fattening duration $(\mathrm{d})$ & 60 & 60 & 7 & NS \\
\hline Cold carcass weight $(\mathrm{kg})$ & 18.4 & 18.8 & 0.9 & NS \\
\hline
\end{tabular}

The data presented are least-squares means for paternal origin, paternal origin $\times$ type of concentrate and initial live weight effects.

${ }^{a}$ RSD: residual standard deviation. ${ }^{\mathrm{b}}$ ADG adjusted by linear regression of the individual growth curve.

NS: not significant $(P>0.20)$.

2 groups ( $60 \mathrm{~d})$ : the lambs were slaughtered at 123 days of age.

\subsection{Ruminal fermentation}

The kinetics of ruminal concentrations of SCFA are presented in Figures 1a, 1b, $1 \mathrm{c}$ and $1 \mathrm{~d}$. The lambs with the $\mathrm{C}$ diet had a significantly higher ruminal concentration of total SCFA than lambs with the P diet after a feeding period of 4 hours or more (respectively, $149 \mathrm{vs} .129 \mathrm{mmol} \cdot \mathrm{L}^{-1}$ for a feeding period of $4 \mathrm{~h}(P<0.05)$ and $186 \mathrm{vs}$. $137 \mathrm{mmol} \cdot \mathrm{L}^{-1}$ for a $6 \mathrm{~h}$ period $(P<0.01$, Fig. 1a). Ruminal concentration of acetate was not different between the 2 diets for all sampling times $\left(14 \mathrm{mmol} \cdot \mathrm{L}^{-1}\right.$ for fasted lambs and $83 \mathrm{mmol} \cdot \mathrm{L}^{-1}$ after $6 \mathrm{~h}$ of feeding, Fig. 1b). Two hours after the distribution of the diets, the propionate concentration was significantly higher in the $\mathrm{C}$ group than in the $\mathrm{P}$ group (respectively 52 vs. $30 \mathrm{mmol} \cdot \mathrm{L}^{-1}$ for the $2 \mathrm{~h}$ samples $(P<0.01)$ and $88 \mathrm{vs} .41 \mathrm{mmol} \cdot \mathrm{L}^{-1}$ for the $6 \mathrm{~h}$ samples
$(P<0.001$, Fig. 1c). Changes in butyrate concentration were variable with a large individual variability (Fig. 1d), as for isobutyrate, valerate and isovalerate concentrations.

After $6 \mathrm{~h}$ of access to the diet, ruminal proportions of SCFA in lambs fed the $\mathrm{C}$ diet compared to lambs fed the P diet were different: respectively, 43 vs. $62 \%$ acetate $(P<0.001), 47$ vs. $30 \%$ propionate $(P<0.001)$ and 6.0 vs. $6.8 \%$ butyrate (NS). The acetate/propionate ratio was below 1 for the $\mathrm{C}$ diet and over 2 for the $\mathrm{P}$ diet.

SCFA concentration patterns were influenced by the feed intake of the last meal (Tab. III). The total SCFA concentration and the proportion of propionate were positively correlated with the ME intake (respectively, $\mathrm{r}=0.72(P<0.01)$ and $\mathrm{r}=0.75(P<0.01))$. But, the proportion of acetate was negatively correlated with the ME intake $(\mathrm{r}=-0.45$, $P<0.01)$. Butyrate concentration was not correlated with the feed intake. The coefficients of correlation between the isobutyrate 


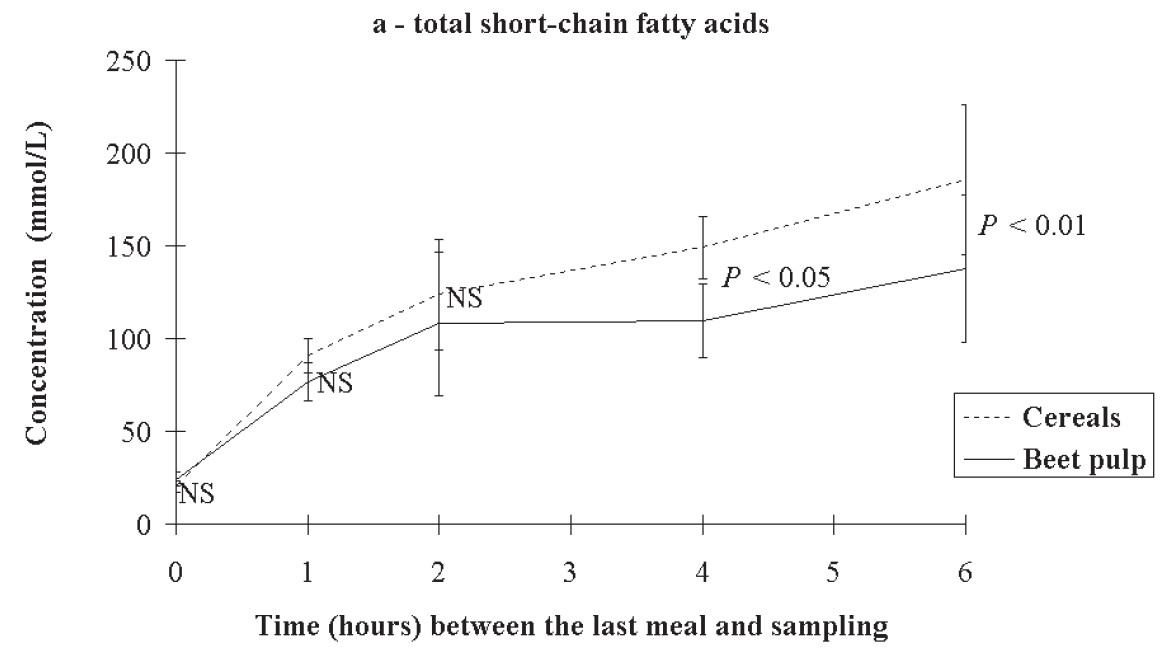

(a)

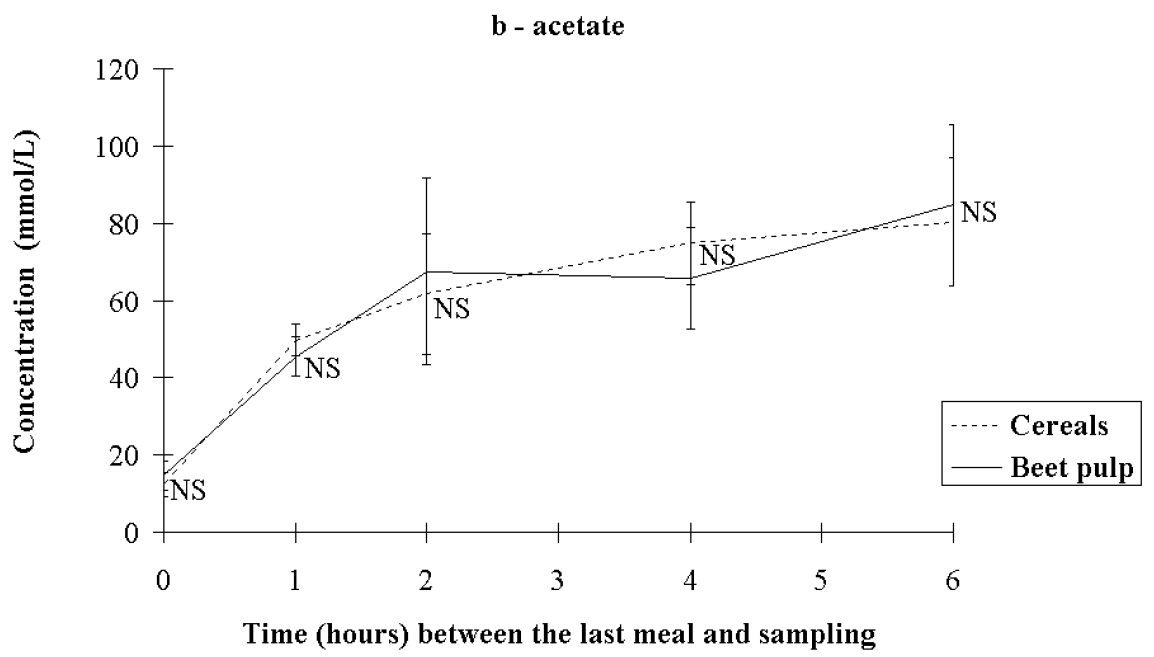

Figure 1. Influence of the type of concentrate on ruminal concentration patterns (mean and standard error) of short-chain fatty acids (a), acetate (b), propionate (c) and butyrate (d) during the first hours of digestion. The rumen samplings were made $0,1,2,4$ or 6 hours after the last meal before slaughter.

and isovalerate concentrations and the feed intake were significant, but they were due to the first measurements obtained on fasted lambs.

\subsection{Plasma metabolites}

The effects of the type of concentrate on plasma concentrations of nutrients and insulin are presented in Table IV. Glucose and BHB concentrations were higher in lambs fed the $\mathrm{P}$ diet than in lambs fed the $\mathrm{C}$ diet $\left(0.84\right.$ vs. $0.86 \mathrm{~g} \cdot \mathrm{L}^{-1}(P=0.12)$ and 41 vs. $28 \mathrm{mg} \cdot \mathrm{L}^{-1}(P<0.01)$, for glucose and $\mathrm{BHB}$ respectively). But no diet effect was observed on insulin, NEFA and lactate concentrations. The insulin concentration was correlated with the ME intake per lamb 


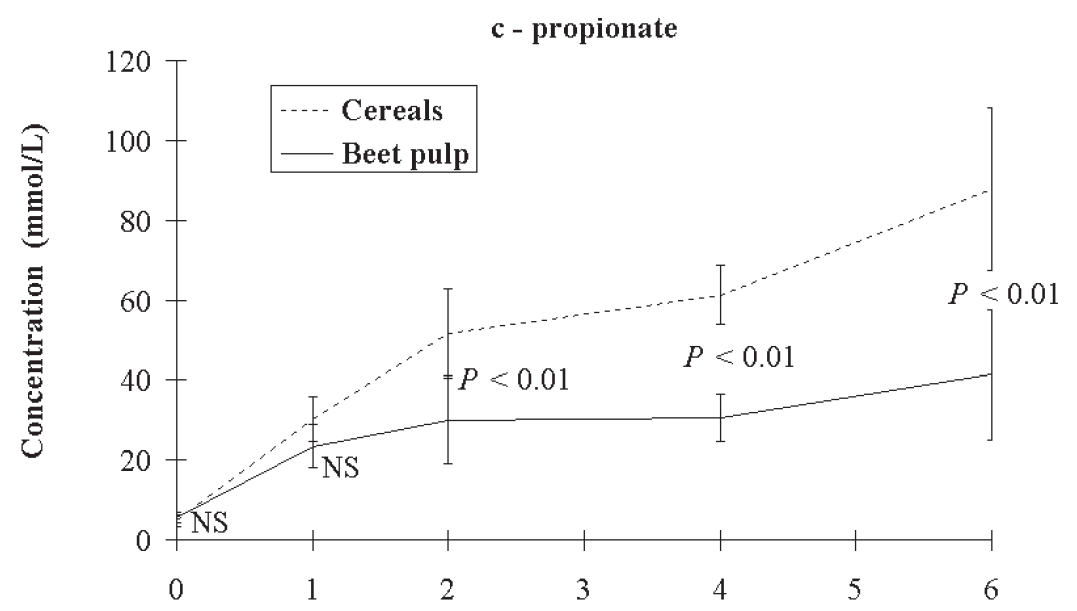

(c)

Time (hours) between the last meal and sampling

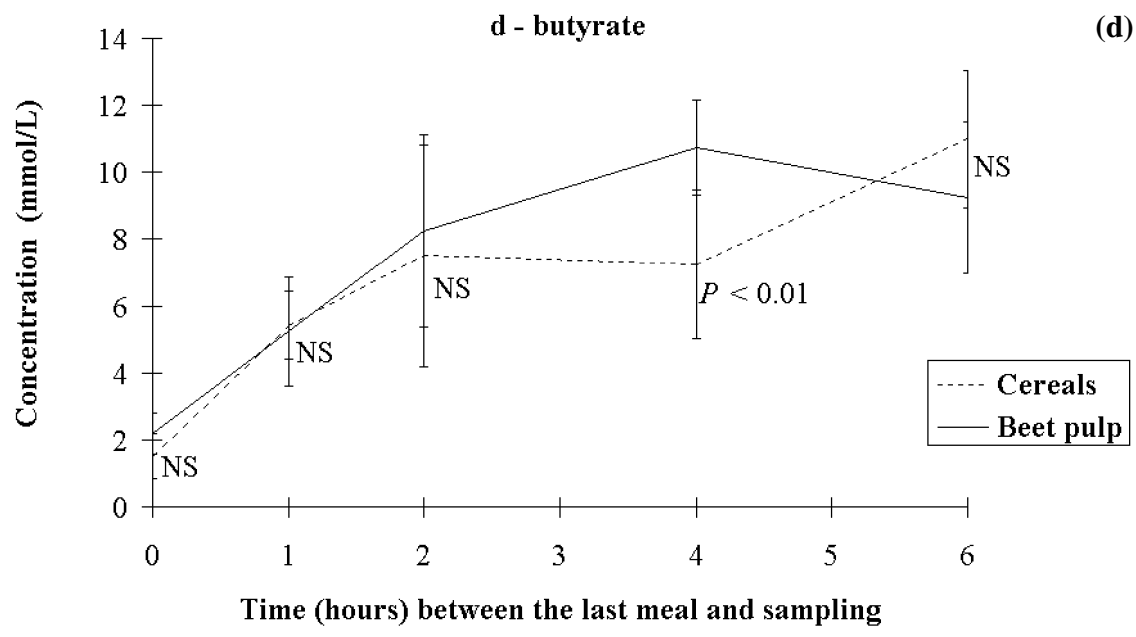

Figure 1. (Continued).

metabolic weight $(\mathrm{r}=0.36, P<0.05)$. The plasma concentrations of the other metabolites were not correlated with the ME intake (Tab. V).

The mean concentration of methylmalonate tended to be lower in the $\mathrm{P}$ group compared to the $\mathrm{C}$ group (respectively, 1.9 vs. $2.8 \mu \mathrm{mol} \cdot \mathrm{L}^{-1}, P=0.09$ ). Although no difference between the 2 sampling days was observed, the diet effect was greater at $t_{-12}$. The mean concentration of methylmalonate was not correlated with the mean energy intake over the experiment. It was however positively correlated with the ADG $(\mathrm{r}=0.46$, $P<0.01)$ and negatively correlated with the energy conversion index $(\mathrm{r}=-0.49$, $P<0.01)$. At $\mathrm{t}_{-12}$ and $\mathrm{t}_{-36}$, the plasma concentration of methylmalonate was negatively correlated with the BHB concentration obtained the same day (respectively for $\mathrm{t}_{-12}$ and $\mathrm{t}_{-36}, \mathrm{r}=-0.50$ and $\mathrm{r}=-0.36, P<0.01$ ). At $t_{-36}$, it was also positively correlated with the insulin concentration $(\mathrm{r}=0.3, P<0.01)$. 


\subsection{Carcass quality}

The conformation of the lambs' carcasses were intermediate since $60 \%$ of them were scored $\mathrm{R}$ and $40 \%$ were scored $\mathrm{O}$.

There was no difference in the fattening status between the 2 groups whatever the criterion used (Tab. VI). The weight of omental and perirenal adipose tissues and the dorsal fat thickness were greater in lambs with a high index of energy conversion or a high insulin concentration (Tab. V).

Whatever the diet, the firmness of subcutaneous fat was of poor quality, since approximately $75 \%$ of the carcasses were scored 3,4 or 5 , leading to commercial problems (Fig. 2a). Twelve carcasses (24\%)

Table III. Correlation coefficients between ruminal fermentation and metabolic energy intake during the last meal.

\begin{tabular}{lr}
\hline & ME intake \\
\hline Total SCFA & 0.72 \\
$\%$ acetate & -0.45 \\
$\%$ propionate & 0.75 \\
$\%$ isobutyrate & -0.81 \\
$\%$ butyrate & -0.29 \\
$\%$ isovalerate & -0.48 \\
$\%$ valerate & -0.01
\end{tabular}

$n=47, P<0.01$ for $r>0.37$. were judged firm or very firm (scores 1 and 2), 21 (43\%) slightly soft (score 3), $13(27 \%)$ soft (score 4 ) and $3(6 \%)$ very soft and oily (score 5). Even though the softness problems seemed to be less acute with the $\mathrm{P}$ diet, the firmness was not significantly different between the 2 groups of lambs (mean score of 3.1). However, the lambs which had either higher energy intake per unit of metabolic weight or greater ADG showed more accurate softness problems $(\mathrm{r}=0.37(P<0.01)$ and $\mathrm{r}=0.28(P<0.05)$ respectively; Tab. V). On the contrary, subcutaneous fat was firmer when the lambs were heavier at the beginning of the experiment $(\mathrm{r}=-0.30, P<0.05)$. No relationship between firmness and methylmalonate concentration was observed.

As with firmness, the colour of fat was not judged satisfactory with either diet. Less than $30 \%$ of the carcasses were judged light (scores 1 and 2) while another third showed brown-red fat (scores 4 and 5; Fig. 2b). The type of the diet had no effect on the colour of fat (mean score of 3.2). Moreover, the fat colour was graduated when the energy intake per unit of metabolic weight increased $(\mathrm{r}=0.53, P<0.01)$ and when the ADG increased $(\mathrm{r}=0.27, P=0.06$; Tab. V).

The lack of firmness was not systematically associated with a fat colour problem. Twenty-three carcasses had the same score

Table IV. Effect of the type of concentrate on plasma concentrations of nutrients and insulin.

\begin{tabular}{lcccc}
\hline & $\begin{array}{c}\text { Cereal } \\
(n=25)\end{array}$ & $\begin{array}{c}\text { Beet pulp } \\
(n=24)\end{array}$ & RSD $^{\mathrm{a}}$ & Probability \\
\hline Glucose $\left(\mathrm{g} \cdot \mathrm{L}^{-1}\right)$ & 0.84 & 0.86 & 0.04 & $P=0.12$ \\
Insulin $\left(\mathrm{mU} \cdot \mathrm{L}^{-1}\right)$ & 19 & 19 & 4 & $\mathrm{NS}$ \\
Non esterified fatty acids $\left(\mu \mathrm{eq} \cdot \mathrm{L}^{-1}\right)$ & 68 & 62 & 26 & $\mathrm{NS}$ \\
$\beta$-hydroxybutyrate $\left(\mathrm{mg} \cdot \mathrm{L}^{-1}\right)$ & 28 & 41 & 9 & $P<0.01$ \\
Lactate $\left(\mathrm{mmol} \cdot \mathrm{L}^{-1}\right)$ & 2.02 & 2.03 & 0.30 & $\mathrm{NS}$ \\
Methylmalonate $\left(\mu \mathrm{mol} \cdot \mathrm{L}^{-1}\right)$ & 2.76 & 1.92 & 1.47 & $P=0.09$ \\
\hline
\end{tabular}

The data presented are least-squares means for paternal origin, paternal origin $\times$ type of concentrate and initial live weight effects.

${ }^{a}$ RSD: residual standard deviation.

NS: not significant $(P>0.20)$ 
Table V. Correlation coefficients between growth performances, plasma concentrations of nutrients and insulin and carcass quality.

\begin{tabular}{|c|c|c|c|c|c|c|c|c|c|}
\hline & Glucose & Insulin & $\begin{array}{l}\beta \text {-hydroxy- } \\
\text { butyrate }\end{array}$ & $\begin{array}{l}\text { Methyl- } \\
\text { malonate }\end{array}$ & $\begin{array}{l}\text { Dorsal fat } \\
\text { thickness }\end{array}$ & $\begin{array}{l}\mathrm{OM}^{\mathrm{a}} \\
\text { weight }\end{array}$ & $\begin{array}{c}\mathrm{PR}^{\mathrm{b}} \\
\text { weight }\end{array}$ & $\begin{array}{c}\text { Fat } \\
\text { firmness }\end{array}$ & $\begin{array}{l}\text { Fat } \\
\text { colour }\end{array}$ \\
\hline Initial weight & -0.20 & 0.23 & 0.01 & 0.28 & 0.02 & 0.03 & -0.12 & -0.30 & -0.17 \\
\hline ME intake $\cdot \mathrm{kg}^{-1} \mathrm{LW}^{0.75}$ & 0.16 & 0.36 & -0.20 & 0.10 & 0.09 & 0.16 & -0.01 & 0.37 & 0.53 \\
\hline Adjusted $\mathrm{ADG}^{\mathrm{c}}$ & 0.18 & 0.06 & -0.20 & 0.46 & -0.23 & -0.15 & -0.19 & 0.28 & 0.27 \\
\hline Energy conversion index & -0.09 & 0.20 & 0.11 & -0.49 & 0.43 & 0.41 & 0.34 & -0.04 & -0.04 \\
\hline Glucose & & 0.34 & -0.20 & 0.05 & 0.01 & -0.10 & 0.02 & -0.22 & 0.12 \\
\hline Insulin & & & -0.15 & 0.01 & 0.29 & 0.39 & 0.47 & -0.10 & 0.36 \\
\hline $\begin{array}{l}\beta \text {-hydroxybutyrate } \\
\text { Methylmalonate }\end{array}$ & & & & -0.45 & $\begin{array}{l}-0.06 \\
-0.20\end{array}$ & $\begin{array}{r}0.04 \\
-0.14\end{array}$ & $\begin{array}{l}-0.06 \\
-0.07\end{array}$ & $\begin{array}{l}0.02 \\
0.04\end{array}$ & $\begin{array}{l}-0.20 \\
-0.03\end{array}$ \\
\hline
\end{tabular}

$n=49, P<0.01$ for $\mathrm{r}>0.36, P<0.05$ for $\mathrm{r}>0.28$.

a Omental weight/hot carcass weight. ${ }^{\mathrm{b}}$ Perirenal weight/hot carcass weight. ${ }^{\mathrm{c}} \mathrm{ADG}$ adjusted by linear regression of the individual growth curve. 
Table VI. Effect of the type of concentrate on fattening status.

\begin{tabular}{|c|c|c|c|c|}
\hline & $\begin{array}{c}\text { Cereal } \\
(n=25)\end{array}$ & $\begin{array}{l}\text { Beet pulp } \\
(n=24)\end{array}$ & $\mathrm{RSD}^{\mathrm{a}}$ & Probability \\
\hline Fatness score & 2.2 & 2.2 & 0.4 & NS \\
\hline Dorsal fat thickness (mm) & 4.6 & 4.4 & 1.1 & NS \\
\hline Sternal fat thickness (mm) & 10.5 & 10.0 & 2.1 & NS \\
\hline $\mathrm{OM}^{\mathrm{b}}$ weight/hot carcass weight $(\%)$ & 3.54 & 3.28 & 1.02 & NS \\
\hline $\mathrm{PR}^{\mathrm{c}}$ weight/hot carcass weight (\%) & 1.30 & 1.28 & 0.38 & NS \\
\hline
\end{tabular}

The data presented are least-squares means for paternal origin, paternal origin $\times$ type of concentrate and initial live weight effects.

${ }^{\mathrm{a}} \mathrm{RSD}$ : residual standard deviation. ${ }^{\mathrm{b}} \mathrm{OM}$ : omental adipose tissue. ${ }^{\mathrm{c}} \mathrm{PR}$ : perirenal adipose tissue.

NS: not significant $(P>0.20)$.

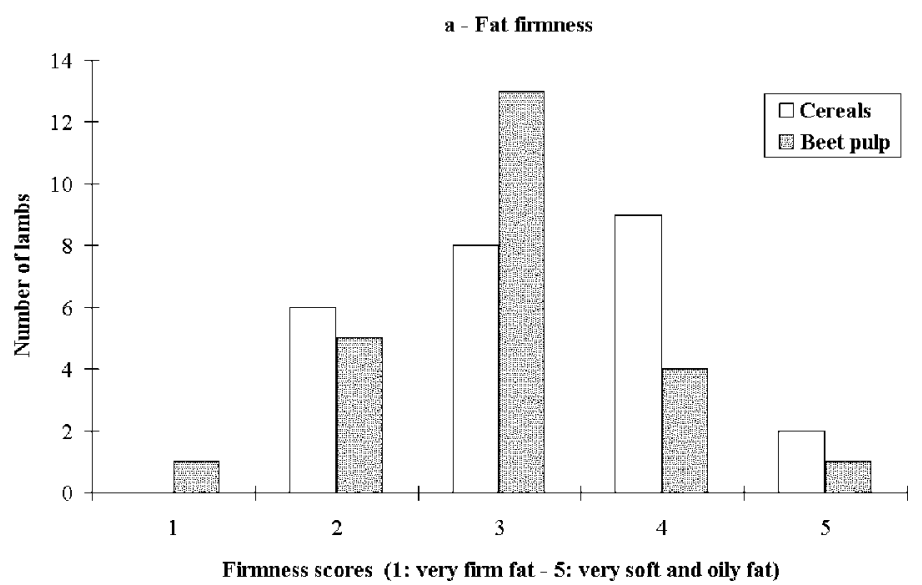

(a)

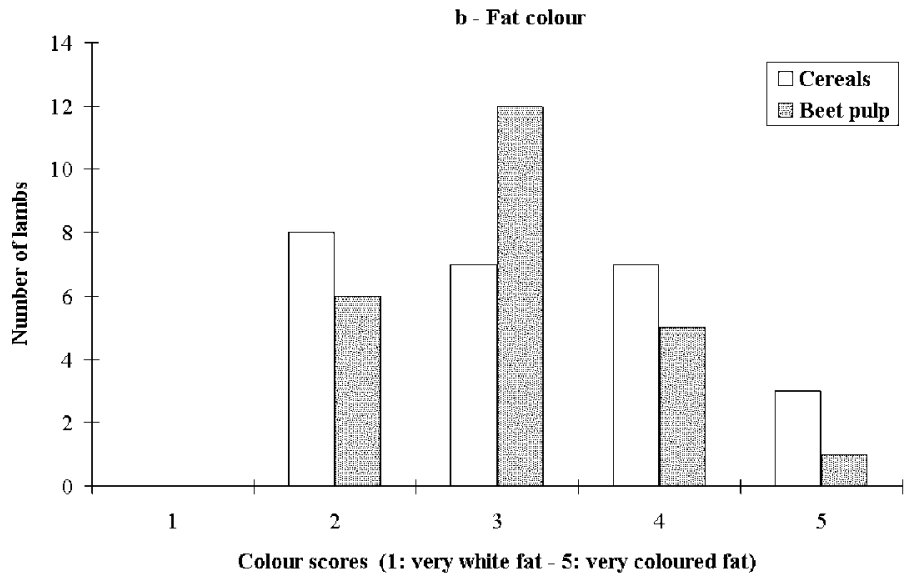

Figure 2. Influence of the type of concentrate on the number of lambs in each class for the firmness (a) and colour (b) of subcutaneous adipose tissues $(n=49)$. 
for the firmness and colour of fat. Twelve carcasses had a higher score for the firmness index and 14 for the colour index.

\section{DISCUSSION}

\subsection{Feeding and growth performance}

In the present study, dry matter and energy intake were close to the values obtained by Normand et al. [24] under similar conditions. The DM intake was lower for the cereal-based diet compared to the beet pulp-based diet, as observed by several authors [20,31]. The increase in intake for the $\mathrm{P}$ group may be due to a metabolic regulation of intake to compensate for the slightly lower energy density of the beet pulp diet compared to the cereal diet, according to the energy values of the 2 diets calculated from the equations of GigerReverdin et al. [15].

The ADG were lower than those in the first experiment of Normand et al. [24]. In the present study, the differences in ADG between the two diets were small and close to the values observed by Kinsella and L'Estrange [20, trial 1] and Thériez and Brun [31].

\subsection{Rumen fermentation}

The SCFA concentrations during the first hours after the meal distribution were higher compared to the results of several studies comparing fermentation patterns of diets based on cereals or on beet pulp, 2 to 3 hours after intake [4, 6, 23, 31]. This difference is particularly great for the cereal diet. Due to the $12 \mathrm{~h}$ fast before the last distribution of the meal, the DM intake during the first hour (an average of $480 \mathrm{~g} \mathrm{DM}$ ) was high. It should have strengthened the fermentative response.

The method used in the present experiment to study the fermentation patterns was not very accurate since a lamb gave only one pattern. However, ruminal fermenta- tion of lambs from the $\mathrm{C}$ diet was logically more intense [29] and led to a higher concentration of propionate, a lower concentration of acetate and also more or less butyrate than lambs from the $\mathrm{P}$ diet [32]. The acetate/propionate ratio was low for both groups which may show an excess of energy in the rumen. In the present study, the propionate proportions were higher than those of Thériez and Brun [31], especially for the cereal-based diet $(+18 \%)$, and the butyrate proportions were $10 \%$ lower. The literature shows some variability of fermentation patterns of cereal-based diets (acetate/propionate ratio from 1.6 to 2.6) or beet pulp-based diets (acetate/propionate ratio from 2.0 to 3.0). This may indicate variability in the chemical compositions of these diets and in the rumen micro-organisms of the animals.

Nevertheless, the present study confirms common knowledge on the fermentation of these diets and especially the greater production of propionate in cereal-based diets [12]. In this experiment, the hypothesis of similar propionate production between the 2 diets did not seem to be confirmed.

\subsection{Plasma metabolites}

The concentrations of BHB and to a lesser extent of glucose were higher in the $\mathrm{P}$ group than in the $\mathrm{C}$ group. This confirms previous observations [24]. The higher concentration of $\mathrm{BHB}$ with the $\mathrm{P}$ diet may come from a higher production of butyrate during fermentation of feed rich in cell walls [18], although the results of this experiment do not permit any conclusion on this particular point. This may also arise from the fermentation of saccharose present in dry pulp [11].

Plasma concentration of methylmalonate was largely below $10 \mu \mathrm{mol} \cdot \mathrm{L}^{-1}$, which is the upper physiological concentration for lambs reared with a barley-based diet [25]. It is very unlikely that the lambs were either cobalt or vitamin $B_{12}$ deficient. 
The coefficient of correlation between insulin and methylmalonate concentrations seems logical since both the production of this metabolite and of insulin are favoured by a high blood concentration of propionate $[2,14]$. The lambs seemed to be in this physiological status with regards to ruminal fermentation of each diet.

\subsection{Carcass quality}

As in several other trials [16, 31], no difference in the fattening status of lambs were observed between the cereal- and beet pulpbased diets. This was in agreement with the energy conversion index which was similar for both groups.

No significant effect of beet pulp incorporation into the diet on fat firmness was observed. This confirms previous results observed by Kinsella and L'Estrange [20], Thériez and Brun [31] and Sagot (personal communication). The lack of firmness of subcutaneous fat may be partly due to the high levels of energy intake and to the high growth rates in both groups $[8,9]$. Growth rate seems to be one of the main factors influencing fat firmness. When differences in ADG between the diets occurred, they may have hidden the effect of the feed type as seen in the trials of Matray et al. [22] and Normand et al. [24]. But, when ADG differences were small, the type of feed may have had a direct effect on carcass quality. However, this effect was probably minor for the beet pulp diet.

Firmness problems may also be linked to high ruminal production of propionate. In the present study, the high propionate concentration (over $40 \mathrm{mmol} \cdot \mathrm{L}^{-1}$ ) may have led to the inability of the liver to metabolise it into glucose [14]. Therefore propionate or methylmalonate arising from propionate metabolism may be used for the synthesis of fatty acids with low melting points.

Differences in plasma concentration of methylmalonate between the 2 diets may be related to the 2 different levels of propionate production observed in the rumen. However, the expected relationship between this concentration and fat firmness scores was not observed. This may be due to the lack of precision of the firmness measurements which were visual and manual. To be more accurate, it may be necessary to analyse the fatty acid composition of the subcutaneous adipose tissue and to study the relationships between the methylmalonate concentration and the fatty acids potentially arising from this metabolite. Moreover, plasma concentrations of methylmalonate were measured on two different days and may be subject to post-prandial variations. This may as well explain the lack of relationship between methylmalonate concentration and fat firmness. Another explanation may be the site of blood sampling. The concentrations of metabolites in jugular blood reflect their concentrations in the systemic circulation and not their availability for the adipose tissues. Finally, with regards to the high propionate production and the high incidence of soft adipose tissue in the present experiment, the low concentration of methylmalonate, $2.3 \mu \mathrm{mol} \cdot \mathrm{L}^{-1}$ on the average, may raise a question on the major importance of the hepatic release of methylmalonate. It may be interesting to study the metabolism of propionate into methylmalonate in the adipocytes.

The colour of fat was not significantly influenced by the type of the diet as observed by Normand et al. [24]. On the contrary, Matray et al. [22] and Sagot (personal communication) observed an improvement of fat colour with diets rich in beet pulp. In their experiments, the substitution of cereals by beet pulp decreased the energy intake leading to confusing effects between the "type" and the "intake" of energy.

\section{CONCLUSIONS}

For lambs with high and similar energy intake and growth rate, the substitution of 
cereals by beet pulp did not improve the subcutaneous fat quality of carcasses. The growth rate effect seems to predominate the feed type effect when comparing cereals and beet pulp. The ruminal production of propionate with the diet rich in beet pulp was lower compared to the cereal-based diet. However, it remained high and may have led in both cases to a lack of firmness of the adipose tissue. Despite the high incidence of soft fat, plasma concentration of methylmalonate was low and questions the supposed high hepatic release of methylmalonate. These results need to be confirmed by analysing the diet effect on the fatty acid composition of subcutaneous adipose tissue and by more specifically studying the propionate metabolism in adipocytes.

\section{ACKNOWLEDGEMENTS}

The authors wish to thank the people of the experimental unit of Theix and Françoise Ternois for skilful technical assistance. We also thank Dr. Niels Bastian Kristensen for his methodological support and his useful comments and Thierry Brun for statistical analyses of data.

\section{REFERENCES}

[1] Bas P., Morand-Fehr P., Van Quackebeke E., Cazes J.P., Étude du caractère mou des gras de couverture de certaines carcasses d'agneaux, in: $31^{\text {e }}$ Réunion annuelle de la Fédération Européenne de Zootechnie, Munich, 1-4 septembre 1980.

[2] Bas P., Lloret-Pujol M., Schmidely P., Rouzeau A., Sauvant D., Influence de la gestation sur la néoglucogenèse à partir du propionate chez la chevrette, Ann. Zootech. 43 (1994) 310.

[3] Bas P., Giral B., Rouzeau A., Défauts de qualité des gras de couverture des agneaux de race Lacaune élevés en bergerie, in: Flamant J.C. Gabiña D., Espejo Diaz M. (Eds.), Proceedings of the International Symposium on basis of the quality of typical Mediterranean animal products, Badajoz, 29 September-2 October 1996 , Wageningen Pers, Wageningen, EAAP Publication 90, 1998, pp. 451-455.

[4] Berge P., Dulphy J.P., Étude des interactions entre fourrage et aliment concentré chez le mouton. II - Facteurs de variation de la digestibilité, Ann. Zootech. 40 (1991) 227-246.
[5] Berthelot V., Normand J., Bas P., Kristensen N.B., Softness and fatty acid composition of subcutaneous adipose tissue, and methylmalonic acid concentrations in the plasma of intensively reared lambs, Small Rum. Res. (2001) in press.

[6] Bhattacharya A.N., Khan T.M., Uwayjan M. Dried beet pulp as a sole source of energy in beef and sheep rations, J. Anim. Sci. 41 (1975) 616-621.

[7] Bozzolo G., Bouillier-Oudot M., Composition en acides gras, fermeté et coloration du tissu adipeux sous-cutané des carcasses d'agneaux, Ann. Zootech. 48 (1999) 47-58.

[8] Bozzolo G., Bouillier-Oudot M., De Boisseson E., Ghassan E., Grasset D., Influence des performances zootechniques sur les caractéristiques des tissus adipeux d'agneaux de bergerie, sevrés précocement et alimentés avec un régime à forte concentration énergétique, Ann. Zootech. 39 (1990) 77-94.

[9] Busboom J.R., Miller G.J., Field R.A., Crouse J.D., Riley M.L., Nelms G.E., Ferrell C.L., Characteristics of fat from heavy ram and wether lambs, J. Anim. Sci. 52 (1981) 83-92.

[10] Cazes J.P., Vallade C., Van Quackebeke E., Effect of concentrates on quality of subcutaneous adipose tissue of lamb carcasses, World Rev. Anim. Prod. 15 (1990) 55-62.

[11] Demarquilly C., Digestibilité, valeur nutritive et ingestibilité des betteraves de différentes teneurs en matière sèche, Ann. Zootech. 21 (1972) 415-428.

[12] Duncan W.R.H., Orskov E.R., Garton G.A., Fatty acid composition of triglycerides of lambs fed on barley-based diets, Proc. Nutr. Soc. 31 (1972) 19A-20A.

[13] Duncan W.R.H., Orskov E.R., Garton G.A., Effect of different dietary cereals on the occurrence of branched-chain fatty acids in lamb fat, Proc. Nutr. Soc. 33 (1974) 81A-82A.

[14] Garton G.A., De B. Hovell F.D., Duncan W.R.H., Influence of dietary volatile fatty acids on the fatty-acid composition of lamb triglycerides, with special reference to the effect of propionate on the presence of branched-chain components, Brit. J. Nutr. 28 (1972) 409-416.

[15] Giger-Reverdin S., Aufrère J., Sauvant D., Demarquilly C., Vermorel M., Prediction of the energy values of compound feeds for ruminants, Anim. Feed Sci. Technol. 48 (1994) 73-98.

[16] Herve M.P., Williams G.L., The effects of dried sugar beet pulp and barley based diets on growth and carcass characteristics of Welsh mountain male lambs, Anim. Prod. 26 (1978) 379.

[17] INRA, Alimentation des bovins, ovins et caprins, INRA, Paris, 1988.

[18] Jarrige R., Ingestion et digestion des aliments, in: INRA (Eds.), Alimentation des bovins, ovins et caprins, INRA, Paris, 1988, pp. 29-56. 
[19] Jouany J.P., Volatile fatty acid and alcohol determination in digestive contents, silage juices, bacterial cultures and anaerobic fermentor contents, Sci. Aliments 2 (1982) 131-144.

[20] Kinsella A.J., L'Estrange J.L., The performance of lambs fed indoors on concentrate diets based on whole barley or mollassed beet pulp with or without supplementation with monensin sodium, Anim. Prod. 30 (1980) 483

[21] Legrand I., Dossier qualité du gras (1 ${ }^{\text {re }}$ partie), Pâtre 411 (1994) 21-31.

[22] Matray M., Sagot L., Van Quackebeke E. Influence de la composition du régime d'engraissement sur la qualité des carcasses d'agneaux, Renc. Rech. Ruminants 1 (1994) 205-208.

[23] Muller A., Béranger C., Utilisation des pulpes de betteraves déshydratées en complément d'ensilage d'herbe par les bovins en croissance et à l'engrais, Bull. Tech. CRZV Theix, INRA 35 (1979) 53-58

[24] Normand J., Thériez M., Bas P., Aurousseau B., Sauvant D., Effet de la nature de l'énergie ingérée, céréales vs. pulpes de betteraves, sur les performances de croissance et la qualité des carcasses d'agneaux de bergerie, Ann. Zootech. 48 (1999) 367-380.

[25] O'Harte F.P.M., Kennedy D.G., Blanchflower W.J., Rice D.A., Methylmalonic in diagnosis of cobalt deficiency in barley-fed lambs, Brit. J. Nutr. 62 (1989) 729-738.
[26] Pearce J., Chestnutt D.M.B., A comparison of the fatty acid composition of adipose tissue triglyceride from grass-fed and intensivelyreared lambs, Proc. Nutr. Soc. 33 (1974) 99A-100A.

[27] SAS Institute Inc., SAS/STAT user's Guide, Version 6, 4th ed., SAS Institute Inc., Cary, NC, 1989.

[28] SAS Institute Inc., SAS system for mixed models, SAS Institute Inc., Cary, NC, 1996.

[29] Sauvant D., Van Milgen J., Les conséquences de la dynamique de la digestion des aliments sur le métabolisme ruminal et les performances animales, INRA Prod. Anim. 8 (1995) 353-367.

[30] Scaife J.R., Wahle K.W.J., Garton G.A., Utilization of methylmalonate for the synthesis of branched-chain fatty acids by preparations of chicken liver and sheep adipose tissue, Biochem. J. 176 (1978) 799-804.

[31] Thériez M., Brun J.P., Utilisation des pulpes de betteraves déshydratées par l'agneau à l'engraissement, Bull. Tech. CRZV Theix, INRA 54 (1983) 27-30.

[32] Van Eenaeme C., Istasse L., Gabriel A. Clinquart A., Maghuin-Rogister G., Bienfait J.M., Effects of dietary carbohydrate composition on rumen fermentation, plasma hormones and metabolites in growing-fattening bulls, Anim. Prod. 50 (1990) 409-416.

[33] Ziegler J.H., Miller R.C., Stanislaw C.M., Sink J.D., Effect of roughage on the composition of ovine depot fats, J. Anim. Sci. 26 (1967) 58-63. 